\title{
Energy of the universe in Bianchi-type I models in Møller's tetrad theory of gravity
}

\author{
Oktay Aydoğdu • Mustafa Salti
}

Published online: 11 January 2008

(C) Springer Science+Business Media B.V. 2008

Erratum to: Astrophys Space Sci (2005) 299(3):227-232

DOI 10.1007/s10509-005-7216-7

After investigation and at the request of the President of the Middle East Technical University (METU), Ankara, Turkey, the Editors of Astrophysics and Space Science have decided to retract this paper due to extensive plagiarism of work by others.

The online version of the original article can be found at: http://dx.doi.org/10.1007/s10509-005-7216-7.

O. Aydoğdu $(\varangle) \cdot$ M. Salti

Department of Physics, Graduate School of Natural and Applied Science, Middle East Technical University, 06531 Ankara, Turkey e-mail: oktay231@yahoo.com

M. Salti

e-mail: musts6@yahoo.com 